\title{
The Social Externality of Health Insurance: Evidence from Unemployment Insurance Generosity and Children Mortality ${ }^{1}$
}

Received: 31.01.2021 Available online: 28.06.2021

Wojciech Gryzbowski",

Aleksandra Adamicz ${ }^{* *}$, Hanna Wysocki ${ }^{* * *}$

\section{Abstract}

This paper explores the potential health externality of an important social program in the US, the Unemployment Insurance (UI) program. Exploiting the variations of UI benefits across states and over the years 1970-2000 and applying a difference-indifference-in-difference identification strategy, we find that UI benefits have the potential to reduce child mortality rates. Among mothers fully eligible for the UI benefits compared to non-eligible mothers, a $\$ 1,000$ increase in maximum benefit is associated with 5.3 and 0.24 fewer deaths per 1,000 infants and toddlers, respectively. The effects are robust across various specifications, subsamples, and alternative measures of UI benefits. The results do not appear to be driven by the compositional changes in states' welfare programs or the endogenous economic indicators that cause the changes in $\mathrm{UI}$ laws. The potential mechanisms of impact are improved birth outcomes and better prenatal care during pregnancy. Some policy implications are discussed.

Keywords: Unemployment Insurance, Infant Mortality, Toddler Mortality, Health, Fetal Origin Hypothesis, Birth Outcomes, Panel Data, Prenatal Care

JEL: H75, I12, I18, D62, J13

\section{Introduction}

$\Delta$ relatively large and growing body of Aliterature investigates the externalities of social insurance and welfare programs specifically for health outcomes (Beach and Lopresti, 2019; Figlio et al., 2009; Hsu et al., 2018; Kuka, 2020). The effects of a welfare program are more pronounced among the more vulnerable population who benefit more from expansions in the benefits (Braun et al., 2016; Feldstein, 2005; Leonard and Mas, 2008; Noghani Behambari et al., 2020; Philipson and Becker, 1998). A strand of this literature points to the fact that infants' health outcomes are very sensitive to the welfare of mothers and that welfare payments have the potential to considerably improve infants'

1 Disclosure Statement: The authors have no conflicts of interest to disclose.

Funding Details: The authors received no financial support for the research, authorship, and publication of this article.

University of Warsaw, Department of Economics, Krakowskie Przedmieście 26/28, 00-927 Warszawa, Poland Corresponding Author.

** University of Warsaw, Department of Economics, Krakowskie Przedmieście 26/28, 00-927 Warszawa, Poland

${ }^{* * *}$ University of Warsaw, Department of Economics, Krakowskie Przedmieście 26/28, 00-927 Warszawa, Poland 


\section{Articles}

health outcomes (Chen et al., 2016; Cole and Currie, 1993; Hoynes et al., 2015; Lindo, 2011; Noghanibehambari et al., 2020; Thompson, 2017). For instance, Noghanibehambari et al. (2020) explore the effects of expansions in child support policies as a way to improve the welfare and income of single mothers and find that the enforcement of child support laws was associated with lower child and infant mortality. They suggest that the primary channel of impact is improvements in birth outcomes as a result of better prenatal care.

Unemployment Insurance (UI) program is a joint program between the federal government and state authorities and aims to help unemployed individuals who were laid off overcome the hardship of unemployment. The main purpose of the program is to smooth income and consumption during difficult times (Chetty, 2006; East and Kuka, 2015). However, it has been documented to affect a wide range of outcomes including mental health (Tefft, 2011), smoking and drinking (Fu and Liu, 2019; Lantis and Teahan, 2018), and crime (Beach and Lopresti, 2019; NoghaniBehambari and Maden, 2020). As a temporary increase in income of families during predicaments of unemployment periods, UI benefits have the potential to improve the health of individuals including infants and children. For instance, Kuka (2020) explores the effect of expansions in UI benefits on health outcomes and finds that the unemployed individuals who reside in states with higher benefit payments reveal better health measures than those who reside in states with lower benefits. However, no study has attempted to explore the health externality of UI benefits for infant mortality and children mortality outcomes. This paper aims to fill this gap in the literature.

We explore the effect of expansions in UI benefits on mortality rates among infants and children. Exploiting the variations in UI schedule across US states and over the years
(1970-2000) and using the universe of death records, we find that UI benefits have protective effects for child mortality rates. Moreover, we introduce two channels of impact. First, we show that increases in UI payments improve birth outcomes which in turn can leave the infants with higher health endowment and lower mortality during childhood. Second, the results suggest that the benefits generate incentives among affected pregnant mothers to have better prenatal care in terms of the number of doctor visits and earlier start date of prenatal care.

Quantifying the benefits of social insurance has important policy implications. The design of an optimal welfare program is based on its costs and benefits. The structure of social programs is only sub-optimal if there are externalities that have not been taken into account. The results of this paper help policymakers design an optimal schedule for UI benefits by introducing the positive externalities of the program for children's health outcomes.

The contribution of this paper to the literature is twofold. First, to the best of our knowledge, this is the first study to explore the effect of UI benefits, as a temporary cash transfer to unemployed mothers, on child mortality rates. Second, it adds to the literature on the optimal design of UI schedule by providing evidence on its health externalities. This contribution is not only policy-relevant but also emphasizes the importance of income on mortality rates of children.

The rest of the paper is organized as follows. In section 2, we go over a brief review of the literature. Section 3 introduces the data sources. In section 4 , we discuss the empirical method and identification strategy. Section 5 goes over the main results of the paper. Section 6 provides evidence on the robustness of the results. We introduce two 


\section{Articles}

channels of impact in section 7. Finally, we depart some concluding remarks in section 8.

\section{Literature Review}

UI benefits can affect health outcomes through various channels. First, it can increase the income during times of hardships and providing necessary resources for subsistence. Baird et al. (2011) explore this channel for the case of 59 countries and document that there is a strong negative association between income shocks and infant mortality rates. This channel could also work under its side effects on income inequality. Waldmann (1992) shows that when rich people become richer and the gap between poor and rich widens the rates of infant mortality also increase. The association persists even after controlling for education and medical expenses. Similar studies also relate the income to health outcomes and mortality rates of children (Case et al., 2002; Filmer, 1999; Haile and Niño-Zarazúa, 2018; Hanmer et al., 2003; Kim, 2017; Thakrar et al., 2018; Wolfe and Behrman, 1982).

Second, better welfare could also provide households with better nutrition or generally a better health environment. Several studies point to the fact that nutrition is among the important determinants of infants' health outcomes (Da Silva Lopes et al., 2017; Hambidge and Krebs, 2018; Smith et al., 2017).

Third, the expectation of being protected during unemployment spells generate households to locate in healthier residential areas with lower levels of pollution. (Chay and Greenstone, 2003) exploit the variation in pollution due to the $1981-82$ recession to explore its effect on infant mortality rates. They find that a one-percent reduction in Total Suspended Particulates is associated with a 0.35 percent reduction in infant mortality rates. Other studies also document the
The Health Benefits of Social Insurance: Evidence from

Unemployment Insurance Generosity and Children Mortality

negative externalities of pollution for infants and children's health outcomes (Currie, 2009; Currie et al., 2009; Hill, 2018).

Fourth, the UI benefits increase the lifetime expected earnings and generate an incentive for pregnant mothers to apply better prenatal care and health behavior during prenatal development. Therefore, it has the potential to improve birth outcomes. Hoynes et al. (2015) take advantage of expansions in federally funded Earned Income Tax Credit (EITC) in order to investigate its effects on infants' birth outcomes. They find that an increase of $\$ 1,000$ in the EITC benefits increases the birth weight among black children by 18 grams. They suggest that one of the mechanisms of impact could be better prenatal care and lower negative health behavior such as drinking and smoking all of which has been linked to improved birth outcomes (Barreca and Page, 2015; Colman et al., 2003; Conway and Deb, 2005; Currie and Grogger, 2002; Dave et al., 2019; Markowitz, 2008; Reichman and Florio, 1996; Yan, 2014).

The improved birth outcomes equip infants with better health endowments which in turn help them survive infancy and childhood (Lau et al., 2013; Luke and Keith, 1992; McCormick, 1985; Tomes, 1981). Moreover, the improved birth outcomes also have longterm effects not only for child mortality but also on their cognitive development (Chatterji et al., 2014; Figlio et al., 2014; Fletcher, 2011), education and earnings in adulthood (Almond and Mazumder, 2005; J. R. Behrman and Rosenzweig, 2004; Bharadwaj et al., 2018; Black et al., 2007; Conley et al., 2006; Currie and Moretti, 2007; Maruyama and Heinesen, 2020; Miller and Wherry, 2019), and morbidity and cause-specific mortality in old ages (Behrman et al., 2007; Callaghan et al., 2006; Helgertz and Nilsson, 2019; Lawlor et al., 2006; NoghaniBehambari et al., 2020; Strand 


\section{Articles}

and Kunst, 2006; van den Berg et al., 2011; Yeung et al., 2014).

\section{Data Sources}

This paper uses a wide array of data sources. The mortality data comes from death certificate files of the National Center for Health Statistics. The birth data comes from Natality detailed files extracted from the National Center for Health Statistics. The population data is extracted from (SEER, 2019). Unemployment insurance data is extracted from replication materials of NoghaniBehambari and Maden (2020).

State covariates and their data sources are as follows. Welfare expenditure per capita is extracted from (Kaplan, 2018). GSP and income per capita are extracted from the Bureau of Economic Analysis. The unemployment rate is extracted from the Bureau of Labor Statistics. Average wage data is from the Quarterly Census of Employment and Wages and taken from replication programs of Noghanibehambari et al. (2020). Labor union coverage rates are calculated using Current Population data extracted from Flood et al. (2018).

Table 1 shows the summary statistics of the final sample. On average, there are 11.3 and 2.7 infant and child deaths per 1,000 infants and child population, respectively. The primary proxy to capture $\mathrm{UI}$ benefits is what we call Maximum Benefits which is the maximum duration of UI payments in weeks times maximum weekly payments under the UI program. On average, the maximum benefit between 1970 and 2000 was $\$ 11,103$ in 2000 dollars. Figure 1 shows the geographic distribution of maximum benefit in 1970 and the changes in maximum benefit between 2000 and 1970. The important point regarding this figure is that neither the initial levels of UI benefits nor the changes have geographic clustering which otherwise could have affected the results. Figure 2 illustrates the geographic distribution of child mortality rates across US states in the year 2000.

\section{Empirical Strategy}

\subsection{Endogeneity issues}

The main assumption behind our empirical strategy is that changes in UI laws are orthogonal to other determinants of child mortality. There are two testable concerns regarding this assumption. First, state authorities may change UI benefits as the economic conditions in the state deteriorate. Since the economic conditions are shown to influence child mortality rates they could bias the estimates (Dallolio et al., 2012; Ensor et al., 2010; U.-G. Gerdtham and Johannesson, 2004; U. G. Gerdtham and Johannesson, 2003; Harris, 1988). We explore this source of Endogeneity by running a series of stateby-year panel data regressions of benefits on state-level economic indicators including state and year fixed effects as well as state by year trend. The results, reported in Table 2, rule out this concern. The unemployment rate, employment per population ratio, average wages, labor union coverage, and fertility cannot statistically explain the variations in UI benefits. Second, state authorities may change the composition of other welfare programs to cover the increases in UI benefits and as these programs also have the potential to influence child mortality they could generate Endogeneity problems (Galiani et al., 2005; Goodman-Bacon, 2018a; Noghanibehambari et al., 2020; Sah, 1991). Table 3 shows the results of regressing welfare payments on maximum benefits. There is no evidence of a correlation between the UI maximum benefit and other welfare payments. The fact that there is a positive and strong correlation between total UI payments and maximum benefit confirms the appropriateness of the proxy (column 5). 


\subsection{Econometric Method}

Our empirical strategy compares the outcomes of UI eligible mothers to noneligible mothers (first difference) in states

with higher benefits to states with lower benefits (second difference) over time (third difference). Specifically, we use regressions of the following form:

$$
\begin{gathered}
y_{\text {argst }}=\alpha_{0}+\alpha_{1} \text { UI Eligible }_{\text {argst }} \times \text { Max Ben }_{s t}+\alpha_{2} \text { UI Eligible }_{\text {argst }}+\alpha_{3} \text { Max ben }_{s t} \\
+\alpha_{4} X_{\text {arg }}+\alpha_{5} Z_{s t}+\xi_{\text {arg }}+\zeta_{s} \times T+\eta_{t}+\epsilon_{\text {argst }}
\end{gathered}
$$

Where $y$ is the mortality rate of children in age group a (0-4, 0-1, and 1-4 years old) in race group $r$ (white, black, other) with gender $g$ in state $s$ observed in year $t$. UI Eligible is the share of mothers in the respective cell that are eligible for UI benefits, i.e. are laid off their job. This variable is calculated using Current Population Survey data files in accompany with US census 1970. Max Ben is the UI maximum benefit, our constructed proxy for UI benefits which is explained in section 3. In $X$, we include some average parental characteristics in each cell. These covariates include average mothers' education, mothers' insurance coverage, mothers' eligibility for Medicaid, and mothers' ownership of dwelling. In $Z$, we include some state by year covariates (shown in Table 1). The parameter $\xi$ represents fixed effects for age, race, and gender. The parameter $\eta$ shows the year fixed effects. The state fixed effects, $\zeta$, are interacted with a linear year trend $T$. $\epsilon$ represents a disturbance term. All regressions are weighted using the child population in the respective age group. All standard errors are clustered on the state level.

The coefficient of interest is $a_{1}$ which shows the effect of a change in UI maximum benefit among eligible mothers to non-eligible mothers.

\section{Main Results}

The main results of the paper are reported in Table 4 for different outcomes and specifications. Since the primary coefficient of interest in equation 1 is $a_{1}$, we only show the estimated effects for this parameter. Using the full specification estimations, a $\$ 1,000$ rise in maximum benefits is associated with $1.3,5.4$, and 0.3 fewer deaths to children, infants, and toddlers per 1,000 age-specific child population, respectively. These effects are equivalent to a 48,46 , and 45 percent reduction from the mean of mortality for each respective outcome variable. These effects are quite robust across different specifications where we only include state and year fixed effects (columns 1, 4, and 7), including a wide range of state covariates (columns 2, 5, and 8), as well as adding a linear state by year trend (columns 3, 6, and 9). The estimated coefficients are statistically significant at conventional levels and economically large. These results are in line with other studies that explore the positive externalities of welfare programs on children's health outcomes (Currie et al., 1993; Goodman-Bacon, 2018a, 2018b; Haile and Niño-Zarazúa, 2018; Hu, 1999; Neelakantan, 2009; Noghanibehambari et al., 2020).

It should be noted that although the marginal effects are different their percentage effects are quite similar. For instance, the death rate among infants is 11.31 while among toddlers it is 0.53 deaths per 1,000 agespecific child population. Therefore, a similar shock among these two groups will definitely have higher life-saving effects among infants than toddlers. An alert reader should focus on changes relative to the mean, which in this table is quite similar. 


\section{Articles}

The second fact to note is the small R-squared for regression. The reported R-squared in models are quite similar and in some cases even higher than those reported in the literature (see, for instance, (Noghanibehambari et al., 2020b)). Besides, child mortality is an incidence that is highly prevalent among low birth weight newborns and those prematurely born infants (Da Silva Lopes et al., 2017; Luke and Keith, 1992; McCormick, 1985). These outcomes are highly associated with genetic attributes of mothers and geographic features and economy-wide characteristics (included in state and time fixed effects) as well as welfare programs (included in UI benefit variable) can only marginally influence these outcomes. Thus, it is not surprising that the R-squared is low in various models.

\section{Robustness Checks}

Table 5 shows the results across subsamples based on gender (columns 1 and 2) and race (columns 3 and 4). The results show that boys are more affected by changes in benefits. A $\$ 1,000$ change in UI maximum benefit is associated with 5.9 fewer deaths among boys while it causes 4.6 fewer deaths among girls. This pattern holds for all three outcome variables. Besides, the effects are more pronounced among black children and considerably smaller among white children. These are in line with the literature that minorities benefit more from increases in income and welfare (Hoynes et al., 2015; Noghanibehambari et al., 2020; Shen, 2018).

To search for the robustness of the results based on the constructed proxy of UI benefits, Table 6 shows the results where we replace UI maximum benefit with UI maximum weekly pay (columns 1, 3, and 5) and with the log of UI maximum benefit (columns 2, 4, and 6). The results are statistically significant and economically similar to the main results.
For instance, looking at column 2 and log of maximum benefit, an 8 percent rise in maximum benefits (equivalent to about $\$ 900$ change from the mean) is associated with 1.29 fewer child death per 1,000 child population. This is very similar to the 1.28 unit change of column 3 in Table 4 as a $\$ 1,000$ shock to the level of maximum benefits.

\section{Mechanisms of Impact}

One potential channel of impact through which UI benefits may affect child mortality is improvements in birth outcomes as the adverse birth outcomes are shown to be associated with higher rates of mortality during infancy and childhood (Conley et al., 2006; Lau et al., 2013, 2013; Luke and Keith, 1992; McGovern, 2019; Paneth, 1995). Using birth data between the years 1970-2000 and applying the same strategy as in equation 1, Table 7 shows the results of maximum benefits on infants' birth outcomes (columns 1-4). A $\$ 1,000$ rise in maximum benefits is associated with roughly 2.6 grams higher birth weight, 0.2 percentage point lower likelihood of low birth weight, 0.3 percentage point lower likelihood of preterm birth, and 0.021 units rise in Apgar score. All the effects are statistically significant and economically large. For instance, the marginal effect of 0.2 percentage points for low birth weight implies a 2.7 reduction from the mean of low birth weight over the sample period.

These effects could partly be explained by changes in mothers' prenatal care. As shown in columns 5 and 6 of Table 7, a $\$ 1,000$ increase in benefits is associated with 0.09 more prenatal doctor visits and 0.04 months reduction in the month prenatal care began. These could act as a potential channel of impact as the quantity and timing of prenatal care is documented to cause improved birth outcomes (Corman et al., 2019; Currie and Grogger, 2002; Hoynes et al., 2015; Joyce, 1999; Sonchak, 2015). 


\section{Articles}

\section{Conclusion}

Understanding the externalities of welfare programs is important for policymakers to design optimal structures and schedules. This paper introduced a positive externality of an important social program in the US, the Unemployment Insurance program. Exploiting the state-year variations of $\mathrm{UI}$ benefits between the years 1970-2000 and applying a difference-in- difference-indifference identification strategy, we found that UI benefits have the potential to reduce child death rates. Among mothers fully eligible for the UI benefits to non-eligible mothers, a $\$ 1,000$ increase in maximum benefits is associated with 5.3 and 0.24 fewer deaths per 1,000 infants and toddlers, respectively. These effects are equivalent to a reduction of 46 and 45 percent from the mean of infant and toddler mortality rates over the sample period.

The effects were robust across specifications and subsamples with larger effects among boys and minorities. The results were also robust to alternative measures of UI benefits. We showed that one potential channel of impact could be an improvement in birth outcomes. A $\$ 1,000$ increase in benefits is associated with a 0.2 and 0.3 percentage point reduction in the likelihood of low birth weight and preterm birth. The higher quantity of prenatal care and better timing of prenatal care could partly explain the effects on birth outcomes and subsequently child mortality rates.

\section{References}

Almond, D., and Mazumder, B. (2005). The 1918 influenza pandemic and subsequent health outcomes: $\{A n\}$ analysis of $\{$ SIPP $\}$ data. American Economic Review, 95(2), 258-262.

Baird, S., Friedman, J., and Schady, N. (2011). Aggregate income shocks and infant mortality in the developing world. Review of Economics
The Health Benefits of Social Insurance: Evidence from

Unemployment Insurance Generosity and Children Mortality

and Statistics, 93(3), 847-856. https://doi. org/10.1162/REST_a_00084

Barreca, A., and Page, M. (2015). A Pint for A Pound? Minimum Drinking Age Laws and Birth Outcomes. Health Economics, 24(4), 400418. https://doi.org/10.1002/hec.3026

Beach, B., and Lopresti, J. (2019). LOSING BY LESS? IMPORT COMPETITION, UNEMPLOYMENT INSURANCE GENEROSITY, AND CRIME. Economic Inquiry, 57(2), 1163-1181. https://doi.org/10.1111/ ecin.12758

Behrman, J. R., and Rosenzweig, M. R. (2004). Returns to birthweight. In Review of Economics and Statistics (Vol. 86, Issue 2, pp. 586-601). https://doi.org/10.1162/003465304323031139

Behrman, R. E., Butler, A. S., and others. (2007). Preterm birth: causes, consequences, and prevention.

Bharadwaj, P., Lundborg, P., and Rooth, D. O. (2018). Birth weight in the long run. Journal of Human Resources, 53(1), 189-231. https://doi. org/10.3368/jhr.53.1.0715-7235R

Black, S. E., Devereux, P. J., and Salvanes, K. G. (2007). From the cradle to the labor market? The effect of birth weight on adult outcomes. The Quarterly Journal of Economics, 122(1), 409-439. https://doi. org/10.1162/qjec.122.1.409

Braun, R. A., Kopecky, K. A., and Koreshkova, T. (2016). Old, Sick, Alone, and Poor: A Welfare Analysis of Old-Age Social Insurance Programmes. The Review of Economic Studies, 84(2), rdw016. https://doi.org/10.1093/ restud/rdw016

Callaghan, W. M., MacDorman, M. F., Rasmussen, S. A., Qin, C., and Lackritz, E. M. (2006). The contribution of preterm birth to infant mortality rates in the United States. Pediatrics, 118(4), 1566-1573. https://doi. org/10.1542/peds.2006-0860

Case, A., Lubotsky, D., and Paxson, C. (2002). Economic status and health in childhood: The 


\section{Articles}

origins of the gradient. American Economic Review, 92(5), 1308-1334. https://doi. org/10.1257/000282802762024520

Chatterji, P., Lahiri, K., and Kim, D. (2014). Fetal growth and neurobehavioral outcomes in childhood. Economics and Human Biology, 15, 187-200. https://doi.org/10.1016/j. ehb.2014.09.002

Chay, K. Y., and Greenstone, M. (2003). The impact of air pollution on infant mortality: evidence from geographic variation in pollution shocks induced by a recession. The Quarterly Journal of Economics, 118(3), 1121-1167. https://doi.org/10.1162/00335530360698513

Chen, A., Oster, E., and Williams, H. (2016). Why is infant mortality higher in the United States than in Europe? American Economic Journal: Economic Policy, 8(2), 89-124. https://doi.org/10.1257/pol.20140224

Chetty, R. (2006). A general formula for the optimal level of social insurance. Journal of Public Economics, 90(10-11), 1879-1901. https://doi.org/10.1016/j.jpubeco.2006.01.004

Cole, N., and Currie, J. (1993). Welfare and child health: The link between AFDC participation and birth weight. American Economic Review, 83(4), 971-985. https://doi. org/10.2307/2117589

Colman, G., Grossman, M., and Joyce, T. (2003). The effect of cigarette excise taxes on smoking before, during and after pregnancy. Journal of Health Economics, 22(6), 1053-1072. https://doi.org/10.1016/j. jhealeco.2003.06.003

Conley, D., Strully, K. W., and Bennett, N. G. (2006). Twin differences in birth weight: The effects of genotype and prenatal environment on neonatal and post-neonatal mortality. Economics and Human Biology, 4(2), 151-183. https://doi.org/10.1016/j.ehb.2005.12.001

Conway, K. S., and Deb, P. (2005). Is prenatal care really ineffective? Or, is the "devil" in the distribution? Journal of Health Economics,
24(3), 489-513. https://doi.org/10.1016/j. jhealeco.2004.09.012

Corman, H., Dave, D., Reichman, N. E., Corman, H., Dave, D., and Reichman, N. E. (2019). The Effects of Prenatal Care on Birth Outcomes: Reconciling a Messy Literature. In Oxford Research Encyclopedia of Economics and Finance. Oxford University Press. https://doi.org/10.1093/ acrefore/9780190625979.013.375

Currie, J. (2009). Healthy, wealthy, and wise: Socioeconomic status, poor health in childhood, and human capital development. Journal of Economic Literature, 47(1), 87-122. https://doi.org/10.1257/jel.47.1.87

Currie, J., Cole, N., Currie, J., and Cole, N. (1993). Welfare and Child Health: The Link between AFDC Participation and Birth Weight. American Economic Review, 83(4), 971-985. https://econpapers.repec.org/RePEc:aea:aecr ev:v:83:y:1993:i:4:p:971-85

Currie, J., and Grogger, J. (2002). Medicaid expansions and welfare contractions: Offsetting effects on prenatal care and infant health? Journal of Health Economics, 21(2), 313-335. https://doi.org/10.1016/S01676296(01)00125-4

Currie, J., and Moretti, E. (2007). Biology as destiny? Short- and long-run determinants of intergenerational transmission of birth weight. Journal of Labor Economics, 25(2), 231-263. https://doi.org/10.1086/511377

Currie, J., Neidell, M., and Schmieder, J. F. (2009). Air pollution and infant health: Lessons from New Jersey. Journal of Health Economics, 28(3), 688-703. https://doi.org/10.1016/j. jhealeco.2009.02.001

Da Silva Lopes, K., Ota, E., Shakya, P., Dagvadorj, A., Balogun, O. O., Peña-Rosas, J. P., De-Regil, L. M., and Mori, R. (2017). Effects of nutrition interventions during pregnancy on low birth weight: An overview of systematic reviews. In BMJ Global Health (Vol. 2, Issue 3, 


\section{Articles}

p. e000389). BMJ Publishing Group. https:// doi.org/10.1136/bmjgh-2017-000389

Dallolio, L., Di Gregori, V., Lenzi, J., Franchino, G., Calugi, S., Domenighetti, G., and Fantini, M. P. (2012). Socio-economic factors associated with infant mortality in Italy: An ecological study. International Journal for Equity in Health, 11(1), 1-5. https://doi. org/10.1186/1475-9276-11-45

Dave, D. M., Kaestner, R., and Wehby, G. L. (2019). Does public insurance coverage for pregnant women affect prenatal health behaviors? Journal of Population Economics, 32(2), 419-453. https://doi.org/10.1007/ s00148-018-0714-z

East, C. N., and Kuka, E. (2015). Reexamining the consumption smoothing benefits of Unemployment Insurance. Journal of Public Economics, 132, 32-50. https://doi. org/10.1016/j.jpubeco.2015.09.008

Ensor, T., Cooper, S., Davidson, L., Fitzmaurice, A., and Graham, W. J. (2010). The impact of economic recession on maternal and infant mortality: Lessons from history. BMC Public Health, 10(1), 1-9. https://doi.org/10.1186/14712458-10-727

Feldstein, M. (2005). Rethinking social insurance. In American Economic Review (Vol. 95, Issue 1, pp. 1-24). https://doi. org/10.1257/0002828053828545

Figlio, D., Guryan, J., Karbownik, K., and Roth, J. (2014). The effects of poor neonatal health on children's cognitive development? American Economic Review, 104(12), 42054230. https://doi.org/10.1257/aer.104.12.3921

Figlio, D., Hamersma, S., and Roth, J. (2009). Does prenatal WIC participation improve birth outcomes? New evidence from Florida. Journal of Public Economics, 93(12), 235-245. https://doi.org/10.1016/j. jpubeco.2008.08.003

Filmer, D. (1999). Child Mortality and Public Spending on Health: How Much Does Money
The Health Benefits of Social Insurance: Evidence from Unemployment Insurance Generosity and Children Mortality

Matter? The World Bank. https://doi. org/10.1596/1813-9450-1864

Fletcher, J. M. (2011). The medium term schooling and health effects of low birth weight: Evidence from siblings. Economics of Education Review, 30(3), 517-527. https://doi. org/10.1016/j.econedurev.2010.12.012

Flood, S., King, M., Ruggles, S., Warren, J. R., Rodgers, R., Ruggles, S., and Warren, J. R. (2018). Integrated public use microdata series, current population survey: Version 5.0. [dataset]. Minneapolis: University of Minnesota. https://doi.org/10.18128/D030.V5.0.

Fu, W., and Liu, F. (2019). Unemployment insurance and cigarette smoking. Journal of Health Economics, 63, 34-51. https://doi. org/10.1016/j.jhealeco.2018.10.004

Galiani, S., Gertler, P., and Schargrodsky, E. (2005). Water for life: The impact of the privatization of water services on child mortality. Journal of Political Economy, 113(1), 83-120. https://doi.org/10.1086/426041

Gerdtham, U.-G., and Johannesson, M. (2004). Absolute income, relative income, income inequality, and mortality. Journal of Human Resources, 39(1), 228-247.

Gerdtham, U. G., and Johannesson, M. (2003). A note on the effect of unemployment on mortality. Journal of Health Economics, 22(3), 505-518. https://doi.org/10.1016/S01676296(03)00004-3

Goodman-Bacon, A. (2018a). Public insurance and mortality: Evidence from medicaid implementation. Journal of Political Economy, 126(1), 216-262. https://doi. org/10.1086/695528

Goodman-Bacon, A. (2018b). Public Insurance and Mortality: Evidence from Medicaid Implementation. Journal of Political Economy, 126(1), 216-262. https://doi. org/10.1086/695528

Haile, F., and Niño-Zarazúa, M. (2018). Does Social Spending Improve Welfare in Low- 


\section{Articles}

income and Middle-income Countries? Journal of International Development, 30(3), 367-398. https://doi.org/10.1002/jid.3326

Hambidge, K. M., and Krebs, N. F. (2018). Strategies for optimizing maternal nutrition to promote infant development. In Reproductive Health (Vol. 15, Issue 1, pp. 93-99). BioMed Central Ltd. https://doi.org/10.1186/s12978018-0534-3

Hanmer, L., Lensink, R., and White, H. (2003). Infant and child mortality in developing countries: Analysing the data for robust determinants. Journal of Development Studies, 40(1), 101-118. https://doi.org/10.1080/002203 80412331293687

Harris, B. (1988). Unemployment, Insurance and Health in Interwar Britain. In Interwar Unemployment in International Perspective (pp. 149-183). Springer Netherlands. https:// doi.org/10.1007/978-94-009-2796-4_4

Helgertz, J., and Nilsson, A. (2019). The effect of birth weight on hospitalizations and sickness absences: a longitudinal study of Swedish siblings. Journal of Population Economics, 32(1), 153-178. https://doi. org/10.1007/s00148-018-0706-z

Hill, E. L. (2018). Shale gas development and infant health: Evidence from Pennsylvania. Journal of Health Economics, 61, 134-150. https://doi.org/10.1016/j.jhealeco.2018.07.004

Hoynes, H., Miller, D., and Simon, D. (2015). Income, the earned income tax credit, and infant health. American Economic Journal: Economic Policy, 7(1), 172-211. https://doi. org/10.1257/pol.20120179

Hsu, J. W., Matsa, D. A., and Melzer, B. T. (2018). Unemployment insurance as a housing market stabilizer. American Economic Review, 108(1), 49-81. https://doi.org/10.1257/ aer.20140989

Hu, W. Y. (1999). Child support, welfare dependency, and women's labor supply.
Journal of Human Resources, 34(1), 71-103. https://doi.org/10.2307/146303

Joyce, T. (1999). Impact of augmented prenatal care on birth outcomes of Medicaid recipients in New York City. Journal of Health Economics, 18(1), 31-67. https://doi. org/10.1016/S0167-6296(98)00027-7

Kaplan, J. (2018). Annual Survey of State Government Finances 1992-2016: government_finances_1992_2016. InterUniversity Consortium for Political and Social Research [Distributor]. https://doi.org/10.3886/ E101880V1-6901

Kim, K. (2017). The relationships between income inequality, welfare regimes and aggregate health: a systematic review. European Journal of Public Health, 27(3), 397404. https://doi.org/10.1093/eurpub/ckx055

Kuka, E. (2020). Quantifying the benefits of social insurance: Unemployment insurance and health. Review of Economics and Statistics, 102(3), 490-505. https://doi. org/10.1162/rest_a_00865

Lantis, R., and Teahan, B. (2018). The effect of unemployment insurance on alcohol use and abuse following job loss. Economics and Human Biology, 30, 92-103. https://doi. org/10.1016/j.ehb.2018.06.003

Lau, C., Ambalavanan, N., Chakraborty, H., Wingate, M. S., and Carlo, W. A. (2013). Extremely low birth weight and infant mortality rates in the United States. Pediatrics, 131(5), 855-860. https://doi.org/10.1542/peds.20122471

Lawlor, D. A., Sterne, J. A. C., Tynelius, P., Davey Smith, G., and Rasmussen, F. (2006). Association of childhood socioeconomic position with cause-specific mortality in a prospective record linkage study of $1,839,384$ individuals. American Journal of Epidemiology, 164(9), 907-915.

Leonard, J., and Mas, A. (2008). Welfare reform, time limits, and infant health. Journal 


\section{Articles}

of Health Economics, 27(6), 1551-1566. https://doi.org/10.1016/j.jhealeco.2008.05.013

Lindo, J. M. (2011). Parental job loss and infant health. Journal of Health Economics, 30(5), 869-879. https://doi.org/10.1016/j. jhealeco.2011.06.008

Luke, B., and Keith, L. G. (1992). The contribution of singletons, twins and triplets to low birth weight, infant mortality and handicap in the United States. Journal of Reproductive Medicine for the Obstetrician and Gynecologist, 37(8), 661-666. https://europepmc.org/article/ $\mathrm{med} / 1432978$

Markowitz, S. (2008). The effectiveness of cigarette regulations in reducing cases of Sudden Infant Death Syndrome. Journal of Health Economics, 27(1), 106-133. https://doi. org/10.1016/j.jhealeco.2007.03.006

Maruyama, S., and Heinesen, E. (2020). Another look at returns to birthweight. Journal of Health Economics, 70, 102269. https://doi. org/10.1016/j.jhealeco.2019.102269

McCormick, M. C. (1985). The Contribution of Low Birth Weight to Infant Mortality and Childhood Morbidity. New England Journal of Medicine, 312(2), 82-90. https://doi. org/10.1056/nejm198501103120204

McGovern, M. E. (2019). How much does birth weight matter for child health in developing countries? Estimates from siblings and twins. Health Economics, 28(1), 3-22. https://doi. org/10.1002/hec.3823

Miller, S., and Wherry, L. R. (2019). The LongTerm Effects of Early Life Medicaid Coverage. Journal of Human Resources, 54(3), 785-824. https://doi.org/10.3368/jhr.54.3.0816.8173r1

Neelakantan, U. (2009). The impact of changes in child support policy. Journal of Population Economics, 22(3), 641-663. https://doi.org/10.1007/s00148-008-0199-2

NoghaniBehambari, H., and Maden, B. (2020). Unemployment insurance generosity and
The Health Benefits of Social Insurance: Evidence from Unemployment Insurance Generosity and Children Mortality

crime. Applied Economics Letters. https://doi. org/10.1080/13504851.2020.1798337

Noghanibehambari, H., Noghani, F., and Tavassoli, N. (2020). Child Support Enforcement and Child Mortality. Applied Economics Letters. https://doi.org/10.1080/13 504851.2020.1869157

NoghaniBehambari, H., Noghani, F., and Tavassoli, N. (2020a). Early Life Income Shocks and Old-Age Cause-Specific Mortality. Economic Analysis, 53(2), 1-19.

NoghaniBehambari, H., Noghani, F., and Tavassoli, N. (2020b). Child Support Enforcement and Child Mortality. Applied Economics Letters, 1-12. https://doi.org/10.10 80/13504851.2020.1869157

Paneth, N. S. (1995). The problem of low birth weight. The Future of Children / Center for the Future of Children, the David and Lucile Packard Foundation, 5(1), 19-34. https://doi. org/10.2307/1602505

Philipson, T. J., and Becker, G. S. (1998). OldAge Longevity and Mortality-Contingent Claims. Journal of Political Economy, 106(3), 551-573. https://doi.org/10.1086/250021

Reichman, N. E., and Florio, M. J. (1996). The effects of enriched prenatal care services on Medicaid birth outcomes in New Jersey. Journal of Health Economics, 15(4), 455-476. https://doi.org/10.1016/S0167-6296(96)004912

Sah, R. K. (1991). The effects of child mortality changes on fertility choice and parental welfare. Journal of Political Economy, 99(3), 582-606. https://doi.org/10.1086/261768

SEER. (2019). Surveillance, Epidemiology, and End Results (SEER) Program (www.seer. cancer.gov) Research Data (1975-2016). National Cancer Institute, DCCPS, Surveillance Research Program.

Shen, M. (2018). The effects of school desegregation on infant health. Economics 


\section{Articles}

and Human Biology, 30, 104-118. https://doi. org/10.1016/j.ehb.2018.06.002

Smith, E. R., Shankar, A. H., Wu, L. S. F., Aboud, S., Adu-Afarwuah, S., Ali, H., Agustina, R., Arifeen, S., Ashorn, P., Bhutta, Z. A., Christian, P., Devakumar, D., Dewey, K. G., Friis, H., Gomo, E., Gupta, P., Kæstel, P., Kolsteren, P., Lanou, H., ... Sudfeld, C. R. (2017). Modifiers of the effect of maternal multiple micronutrient supplementation on stillbirth, birth outcomes, and infant mortality: a meta-analysis of individual patient data from 17 randomised trials in low-income and middle-income countries. The Lancet Global Health, 5(11), e1090-e1100. https://doi. org/10.1016/S2214-109X(17)30371-6

Sonchak, L. (2015). Medicaid reimbursement, prenatal care and infant health. Journal of Health Economics, 44, 10-24. https://doi. org/10.1016/j.jhealeco.2015.08.008

Strand, B. H., and Kunst, A. (2006). Childhood socioeconomic position and cause-specific mortality in early adulthood. American Journal of Epidemiology, 165(1), 85-93.

Tefft, N. (2011). Insights on unemployment, unemployment insurance, and mental health. Journal of Health Economics, 30(2), 258-264. https://doi.org/10.1016/j.jhealeco.2011.01.006

Thakrar, A. P., Forrest, A. D., Maltenfort, M. G., and Forrest, C. B. (2018). Child Mortality In The US And 19 OECD Comparator Nations: A 50-Year Time-Trend Analysis. Health Affairs, 37(1), 140-149. https://doi.org/10.1377/ hlthaff.2017.0767

Thompson, O. (2017). The long-term health impacts of Medicaid and CHIP. Journal of
Health Economics, 51, 26-40. https://doi. org/10.1016/j.jhealeco.2016.12.003

Tomes, N. (1981). The family, inheritance, and the intergenerational transmission of inequality. Journal of Political Economy, 89(5), 928-958.

Van den Berg, G. J., Doblhammer-Reiter, G., Christensen, K., den Berg, G. J., DoblhammerReiter, G., and Christensen, K. (2011). Being born under adverse economic conditions leads to a higher cardiovascular mortality rate later in life: \{Evidence\} based on individuals born at different stages of the business cycle. Demography, 48(2), 507-530. https://doi. org/10.1007/s13524-011-0021-8

Waldmann, R. J. (1992). Income Distribution and Infant Mortality. The Quarterly Journal of Economics, 107(4), 1283-1302. https://doi. org/10.2307/2118389

Wolfe, B. L., and Behrman, J. R. (1982). Determinants of child mortality, health, and nutrition in a developing country. Journal of Development Economics, 11(2), 163-193. https://doi.org/10.1016/0304-3878(82)90002-5

Yan, J. (2014). The effects of a minimum cigarette purchase age of 21 on prenatal smoking and infant health. Eastern Economic Journal, 40(3), 289-308. https://doi. org/10.1057/eej.2013.42

Yeung, G. Y. C., den Berg, G. J., Lindeboom, M., and Portrait, F. R. M. (2014). The impact of early-life economic conditionson causespecific mortality during adulthood. Journal of Population Economics, 27(3), 895-919. 
Table 1: Summary Statistics

\begin{tabular}{|c|c|c|c|c|c|}
\hline Variable & Observations & Mean & Std. Dev. & Min & Max \\
\hline \multicolumn{6}{|l|}{ Child Mortality Data: } \\
\hline Child Mortality per 1,000 Child (age 0-4) & 47,430 & 2.718 & 10.093 & 0 & 253.471 \\
\hline Infant Mortality per 1,000 Child (age 0-1) & 47,430 & 11.318 & 50.077 & 0 & 1251.392 \\
\hline Toddler Mortality per 1,000 Child (age 1-4) & 47,430 & 0.534 & 1.215 & 0 & 19.140 \\
\hline \multicolumn{6}{|l|}{ Child Mortality Rate by Sex-Gender Cells } \\
\hline Blacks, Girls & 7,905 & 1.376 & 4.597 & 0 & 46.475 \\
\hline Blacks, Boys & 7,905 & 1.719 & 5.726 & 0 & 56.851 \\
\hline Whites, Girls & 7,905 & 4.846 & 13.238 & 0 & 188.388 \\
\hline Whites, Boys & 7,905 & 6.524 & 17.737 & 0 & 253.471 \\
\hline \multicolumn{6}{|l|}{ Infant Mortality Rate by Sex-Gender Cells } \\
\hline Blacks, Girls & 7,905 & 5.856 & 22.858 & 0 & 229.45 \\
\hline Blacks, Boys & 7,905 & 7.308 & 28.478 & 0 & 280.674 \\
\hline Whites, Girls & 7,905 & 19.994 & 66.261 & 0 & 930.077 \\
\hline Whites, Boys & 7,905 & 26.956 & 88.808 & 0 & 1251.392 \\
\hline \multicolumn{6}{|l|}{ Toddler Mortality Rate by Sex-Gender Cells } \\
\hline Blacks, Girls & 7,905 & 0.238 & 0.485 & 0 & 4.839 \\
\hline Blacks, Boys & 7,905 & 0.300 & 0.593 & 0 & 4.946 \\
\hline Whites, Girls & 7,905 & .998 & 1.566 & 0 & 16.344 \\
\hline Whites, Boys & 7,905 & 1.334 & 2.033 & 0 & 19.14 \\
\hline \multicolumn{6}{|l|}{ Children Characteristics: } \\
\hline Age & 47,430 & 2 & 1.414 & 0 & 4 \\
\hline Sex (female $==1$ ) & 47,430 & 0.500 & 0.500 & 0 & 1 \\
\hline white & 47,430 & 0.333 & 0.471 & 0 & 1 \\
\hline black & 47,430 & 0.333 & 0.471 & 0 & 1 \\
\hline other & 47,430 & 0.333 & 0.471 & 0 & 1 \\
\hline \multicolumn{6}{|l|}{ State Characteristics: } \\
\hline GSP per Capita & 47,430 & 39613.195 & 12631.597 & 20500.438 & 151582.670 \\
\hline Unemployment Rate & 47,430 & 6.203 & 2.089 & 2.300 & 17.800 \\
\hline \%Blacks & 47,430 & 10.979 & 10.474 & 0.174 & 69.374 \\
\hline \%Whites & 47,430 & 84.924 & 12.552 & 24.038 & 99.645 \\
\hline \%Males & 47,430 & 48.936 & 0.928 & 46.264 & 54.601 \\
\hline \%Aged 25-55 & 47,430 & 48.543 & 3.521 & 38.793 & 56.139 \\
\hline Average Weekly Wages & 47,430 & 824.885 & 136.097 & 0 & 1991.75 \\
\hline Log Transfers & 47,430 & 17.121 & 1.100 & 13.715 & 19.664 \\
\hline Log Income Maintenance & 47,430 & 14.847 & 1.197 & 11.355 & 17.909 \\
\hline Log Unemployment Insurance Payments & 47,430 & 13.806 & 1.182 & 10.475 & 16.797 \\
\hline Log Other Welfare Payments & 47,430 & 16.955 & 1.102 & 13.164 & 19.466 \\
\hline Minimum Wage & 47,430 & 8.043 & 1.111 & 6.266 & 13.213 \\
\hline Education Expenditure per Capita & 47,430 & 1.430 & 0.466 & 0.458 & 4.878 \\
\hline Health Expenditure per Capita & 47,430 & 0.137 & 0.084 & 0.014 & 0.813 \\
\hline Policing Expenditure per Capita & 47,430 & 0.046 & 0.074 & 0.001 & 0.852 \\
\hline Black Arrest Rate per 100,000 Population & 47,430 & 617.911 & 797.325 & 0 & 7312.297 \\
\hline White Arrest Rate per 100,000 Population & 47,430 & 56.771 & 25.975 & 0 & 231.04 \\
\hline Male Arrest Rate per 100,000 Population & 47,430 & 110.38 & 47.370 & 0 & 415.756 \\
\hline
\end{tabular}


Articles

\begin{tabular}{|c|c|c|c|c|c|}
\hline Variable & Observations & Mean & Std. Dev. & Min & Max \\
\hline UI Maximum Weekly Payments & 47,430 & 417.898 & 99.615 & 229.295 & 923.342 \\
\hline UI Maximum Benefit & 47,430 & 11.103 & 2.979 & 5.962 & 27.700 \\
\hline Log UI Maximum Benefit & 47,430 & 9.282 & 0.249 & 8.693 & 10.229 \\
\hline UI Duration (Weeks) & 47,430 & 26.078 & 0.554 & 26 & 30 \\
\hline \multicolumn{6}{|l|}{ Mothers' Characteristics: } \\
\hline Education $<12$ & 47,430 & 0.133 & 0.063 & 0.035 & 0.403 \\
\hline Education $=12$ & 47,430 & 0.52 & 0.053 & 0.353 & 0.670 \\
\hline Some College & 47,430 & 0.245 & 0.049 & 0.110 & 0.391 \\
\hline Bachelor and Above & 47,430 & 0.102 & 0.070 & 0.018 & 0.397 \\
\hline Ownership of Dwelling & 47,430 & 0.697 & 0.065 & 0.378 & 0.822 \\
\hline Is UI Eligible? & 47,430 & 0.0309 & 0.0217 & 0 & 0.01 \\
\hline \multicolumn{6}{|l|}{ Infants' Characteristics: } \\
\hline Birth Weight (grams) & 47,430 & 3327.982 & 602.795 & 227 & 8165 \\
\hline Gestational Weeks & 47,430 & 39.043 & 2.700 & 17 & 52 \\
\hline Term Birth Weight & 47,430 & 3447.394 & 482.650 & 227 & 8165 \\
\hline Low Birth Weight & 47,430 & 0.072 & 0.259 & 0 & 1 \\
\hline Extremely Low Birth Weight & 47,430 & 0.013 & 0.113 & 0 & 1 \\
\hline Small for Gestational Age & 47,430 & 0.102 & 0.302 & 0 & 1 \\
\hline Preterm Birth & 47,430 & 0.178 & 0.382 & 0 & 1 \\
\hline Low Apgar Score & 47,430 & 0.031 & 0.175 & 0 & 1 \\
\hline
\end{tabular}

Table 2: Endogeneity of UI Benefits to States' Economic Conditions

\begin{tabular}{|c|c|c|c|c|c|c|}
\hline & \multicolumn{6}{|c|}{ Outcome: UI Maximum Benefit } \\
\hline & (1) & (2) & (3) & (4) & (5) & (6) \\
\hline Unemployment Rate & $\begin{array}{c}0.162 \\
(0.152)\end{array}$ & & & & & $\begin{array}{l}-0.143 \\
(0.168)\end{array}$ \\
\hline Employment per Population Ratio & & $\begin{array}{c}0.027 \\
(0.082)\end{array}$ & & & & $\begin{array}{r}0.090 \\
(0.059)\end{array}$ \\
\hline Average Wages & & & $\begin{array}{c}0.017 \\
(0.014)\end{array}$ & & & $\begin{array}{c}0.013 \\
(0.012)\end{array}$ \\
\hline Labor Union Coverage Rate & & & & $\begin{array}{l}-0.034 \\
(0.027)\end{array}$ & & $\begin{array}{l}-0.052 \\
(0.042)\end{array}$ \\
\hline Lag Fertility & & & & & $\begin{array}{l}-0.019 \\
(0.016)\end{array}$ & $\begin{array}{l}-0.014 \\
(0.020)\end{array}$ \\
\hline State FE & Yes & Yes & Yes & Yes & Yes & Yes \\
\hline Year FE & Yes & Yes & Yes & Yes & Yes & Yes \\
\hline State Trend & Yes & Yes & Yes & Yes & Yes & Yes \\
\hline$R^{2}$ & 0.93 & 0.93 & 0.93 & 0.93 & 0.90 & 0.95 \\
\hline Observations & 1,581 & 1,581 & 1,581 & 1,581 & 1,581 & 1,581 \\
\hline
\end{tabular}

Notes. Standard errors, reported in parentheses, are clustered at the state level. All dollar values are converted into 2000 dollars to reflect real values. All regressions are weighted using the average state population over the sample period.

${ }^{\star * *} p<0.01,{ }^{* *} p<0.05,{ }^{*} p<0.1$ 
Table 3: Endogeneity of UI Benefits to States' Other Welfare Programs

\begin{tabular}{lccccccc}
\hline & $\begin{array}{c}\text { Health } \\
\text { Expenditure } \\
\text { per Capita }\end{array}$ & $\begin{array}{c}\text { Education } \\
\text { Expenditure } \\
\text { per Capita }\end{array}$ & $\begin{array}{c}\text { Log Transfer } \\
\text { Receipts }\end{array}$ & $\begin{array}{c}\text { Log Income } \\
\text { Maintenance } \\
\text { Benefits }\end{array}$ & $\begin{array}{c}\text { Log Total UI } \\
\text { Benefits }\end{array}$ & $\begin{array}{c}\text { Log Other } \\
\text { Welfare } \\
\text { Payments }\end{array}$ & $\begin{array}{c}\text { Medicaid } \\
\text { Coverage } \\
\text { Rate }\end{array}$ \\
\cline { 2 - 8 } & $(1)$ & $(2)$ & $(3)$ & $(4)$ & $(5)$ & $(6)$ & $(7)$ \\
\hline Real Maximum & 0.532 & -5.032 & 0.011 & -0.012 & $0.098^{* * *}$ & -0.031 & 0.249 \\
Benefit $(\$ 1,000)$ & $(1.290)$ & $(9.047)$ & $(0.019)$ & $(0.016)$ & $(0.018)$ & $(0.021)$ & $(0.196)$ \\
\hline States Controls & Yes & Yes & Yes & Yes & Yes & Yes & Yes \\
State FE & Yes & Yes & Yes & Yes & Yes & Yes & Yes \\
Year FE & Yes & Yes & Yes & Yes & Yes & Yes & Yes \\
State Trend & Yes & Yes & Yes & Yes & Yes & Yes & Yes \\
$R^{2}$ & 0.79 & 0.84 & 0.98 & 0.95 & 0.85 & 0.98 & 0.60 \\
Observations & 1,581 & 1,581 & 1,581 & 1,581 & 1,581 & 1,581 & 1,581 \\
\hline
\end{tabular}

Notes. Standard errors, reported in parentheses, are clustered at the state level. All dollar values are converted into 2000 dollars to reflect real values. All regressions are weighted using the average state population over the sample period.

$* * * p<0.01,{ }^{* *} p<0.05,{ }^{*} p<0.1$

Table 4: Unemployment Insurance Generosity and Child Mortality Rates

\begin{tabular}{|c|c|c|c|c|c|c|c|c|c|}
\hline & \multicolumn{3}{|c|}{ Outcome: Child Mortality Rate } & \multicolumn{3}{|c|}{ Outcome: Infant Mortality Rate } & \multicolumn{3}{|c|}{ Outcome: Toddler Mortality Rate } \\
\hline & (1) & (2) & (3) & (4) & (5) & (6) & (7) & (8) & (9) \\
\hline UI Maximum Benefit & $\begin{array}{l}-0.117 \\
(0.109)\end{array}$ & $\begin{array}{l}-0.073 \\
(0.080)\end{array}$ & $\begin{array}{l}-0.059 \\
(0.130)\end{array}$ & $\begin{array}{l}-0.181 \\
(0.462)\end{array}$ & $\begin{array}{l}-0.442 \\
(0.414)\end{array}$ & $\begin{array}{l}-0.375 \\
(0.574)\end{array}$ & $\begin{array}{c}0.101^{* * *} \\
(0.026)\end{array}$ & $\begin{array}{c}0.053^{* * *} \\
(0.019)\end{array}$ & $\begin{array}{c}0.077^{\star * *} \\
(0.016)\end{array}$ \\
\hline UI Eligible & $\begin{array}{c}36.870^{* * *} \\
(3.660)\end{array}$ & $\begin{array}{c}27.468^{\star \star * *} \\
(2.695)\end{array}$ & $\begin{array}{c}13.990^{\star * *} \\
(7.514)\end{array}$ & $\begin{array}{c}15.330^{\star * *} \\
(1.190)\end{array}$ & $\begin{array}{c}11.479 * * * \\
(1.492)\end{array}$ & $\begin{array}{c}6.952^{\star * *} \\
(2.874)\end{array}$ & $\begin{array}{c}7.219^{* * *} \\
(0.776)\end{array}$ & $\begin{array}{c}5.281^{* * *} \\
(0.625)\end{array}$ & $\begin{array}{c}4.112^{* * *} \\
(1.340)\end{array}$ \\
\hline $\begin{array}{l}\text { UI Maximum Benefit } \\
\times \text { UI Eligible }\end{array}$ & $\begin{array}{c}-0.860^{\star \star \star} \\
(0.216)\end{array}$ & $\begin{array}{c}-1.219 * \star \star \\
(0.208)\end{array}$ & $\begin{array}{c}-1.283^{* * *} \\
(0.209)\end{array}$ & $\begin{array}{c}-3.656^{* * *} \\
(0.904)\end{array}$ & $\begin{array}{c}-5.101^{* \star *} \\
(0.869)\end{array}$ & $\begin{array}{c}-5.373^{\star \star \star} \\
(0.871)\end{array}$ & $\begin{array}{c}-0.150^{* * *} \\
(0.042)\end{array}$ & $\begin{array}{c}-0.233^{* * *} \\
(0.043)\end{array}$ & $\begin{array}{c}-0.245^{\star \star *} \\
(0.043)\end{array}$ \\
\hline State FE & Yes & Yes & Yes & Yes & Yes & Yes & Yes & Yes & Yes \\
\hline Year FE & Yes & Yes & Yes & Yes & Yes & Yes & Yes & Yes & Yes \\
\hline States Controls & No & Yes & Yes & No & Yes & Yes & No & Yes & Yes \\
\hline State Trend & No & No & Yes & No & No & Yes & No & No & Yes \\
\hline$R^{2}$ & 0.13 & 0.14 & 0.14 & 0.09 & 0.09 & 0.09 & 0.45 & 0.46 & 0.47 \\
\hline Observations & 47,430 & 47,430 & 47,430 & 47,430 & 47,430 & 47,430 & 47,430 & 47,430 & 47,430 \\
\hline
\end{tabular}

Notes. Standard errors, reported in parentheses, are clustered at the state level. All dollar values are converted into 2000 dollars to reflect real values. All regressions are weighted using the average state-level child population over the sample period.

${ }^{* * *} p<0.01,{ }^{* *} p<0.05,{ }^{*} p<0.1$ 


\section{Articles}

Table 5: Heterogeneity of the Effects of Unemployment Insurance Benefits on Children Mortality Rate by Gender and Race

\begin{tabular}{|c|c|c|c|c|}
\hline & Subsample: Boys & Subsample: Girls & Subsample: Blacks & Subsample: Whites \\
\hline & (1) & (2) & (3) & (4) \\
\hline \multicolumn{5}{|c|}{ Panel A. Outcome: Child Mortality Rate } \\
\hline $\begin{array}{l}\text { Ul Maximum Benefit × UI } \\
\text { Eligible }\end{array}$ & $\begin{array}{c}-1.426^{* * *} \\
(0.245)\end{array}$ & $\begin{array}{c}-1.100 * * * \\
(0.192)\end{array}$ & $\begin{array}{c}-1.711^{\star * *} \\
(0.385)\end{array}$ & $\begin{array}{l}0.075 \\
(0.125)\end{array}$ \\
\hline$R^{2}$ & 0.14 & 0.14 & 0.14 & 0.14 \\
\hline Observations & 47,430 & 47,430 & 47,430 & 47,430 \\
\hline \multicolumn{5}{|c|}{ Panel A. Outcome: Infant Mortality Rate } \\
\hline $\begin{array}{l}\text { UI Maximum Benefit × UI } \\
\text { Eligible }\end{array}$ & $\begin{array}{c}-5.965^{* * *} \\
(1.102)\end{array}$ & $\begin{array}{l}-4.608^{\star * *} \\
(0.802)\end{array}$ & $\begin{array}{l}-6.596^{\star \star *} \\
(2.625)\end{array}$ & $\begin{array}{l}0.428^{* * *} \\
(0.582)\end{array}$ \\
\hline$R^{2}$ & 0.09 & 0.09 & 0.09 & 0.09 \\
\hline Observations & 47,430 & 47,430 & 47,430 & 47,430 \\
\hline \multicolumn{5}{|c|}{ Panel A. Outcome: Toddler Mortality Rate } \\
\hline $\begin{array}{l}\text { Ul Maximum Benefit × Ul } \\
\text { Eligible }\end{array}$ & $\begin{array}{c}-0.273^{* * *} \\
(0.052)\end{array}$ & $\begin{array}{c}-0.209 * * * \\
(0.039)\end{array}$ & $\begin{array}{c}0.295^{\star \star *} \\
(0.046)\end{array}$ & $\begin{array}{c}0.136^{\star * *} \\
(0.059)\end{array}$ \\
\hline$R^{2}$ & 0.48 & 0.45 & 0.46 & 0.47 \\
\hline Observations & 47,430 & 47,430 & 47,430 & 47,430 \\
\hline State FE & Yes & Yes & Yes & Yes \\
\hline Year FE & Yes & Yes & Yes & Yes \\
\hline States Controls & Yes & Yes & Yes & Yes \\
\hline State Trend & Yes & Yes & Yes & Yes \\
\hline
\end{tabular}

Notes. Standard errors, reported in parentheses, are clustered at the state level. All dollar values are converted into 2000 dollars to reflect real values. All regressions are weighted using the average state-level child population over the sample period.

$* * * p<0.01,{ }^{* *} p<0.05,{ }^{*} p<0.1$

Table 6: Robustness of the Effects of Unemployment Insurance Generosity to Alternative Measures of UI Benefits

\begin{tabular}{|c|c|c|c|c|c|c|}
\hline & \multicolumn{2}{|c|}{ Outcome: Child Mortality rate } & \multicolumn{2}{|c|}{ Outcome: Infant Mortality rate } & \multicolumn{2}{|c|}{ Outcome: Toddler Mortality rate } \\
\hline & (1) & (2) & (3) & (4) & (5) & (6) \\
\hline $\begin{array}{l}\text { UI Maximum Weekly } \\
\text { Pay } \times \text { UI Eligible }\end{array}$ & $\begin{array}{c}-0.038^{* * *} \\
(0.006)\end{array}$ & & $\begin{array}{c}-0.159^{* * *} \\
(0.025)\end{array}$ & & $\begin{array}{c}-0.007^{* * *} \\
(0.001)\end{array}$ & \\
\hline $\begin{array}{l}\text { Log UI Maximum } \\
\text { Benefit } \times \text { Ul Eligible }\end{array}$ & & $\begin{array}{c}-16.145^{\star \star *} \\
(2.385)\end{array}$ & & $\begin{array}{c}-66.818^{* * *} \\
(9.963)\end{array}$ & & $\begin{array}{c}-3.275^{\star * *} \\
(0.492)\end{array}$ \\
\hline State FE & Yes & Yes & Yes & Yes & Yes & Yes \\
\hline Year FE & Yes & Yes & Yes & Yes & Yes & Yes \\
\hline States Controls & Yes & Yes & Yes & Yes & Yes & Yes \\
\hline State Trend & Yes & Yes & Yes & Yes & Yes & Yes \\
\hline$R^{2}$ & 0.14 & 0.14 & 0.09 & 0.09 & 0.47 & 0.47 \\
\hline Observations & 47,430 & 47,430 & 47,430 & 47,430 & 47,430 & 47,430 \\
\hline
\end{tabular}

Notes. Standard errors, reported in parentheses, are clustered at the state level. All dollar values are converted into 2000 dollars to reflect real values. All regressions are weighted using the average state-level child population over the sample period.

*** $p<0.01$, ${ }^{* *} p<0.05,{ }^{*} p<0.1$ 
Table 7: Potential Mechanism Channel: Birth Outcomes and Mothers' Health Behavior during Pregnancy

\begin{tabular}{|c|c|c|c|c|c|c|}
\hline & \multicolumn{4}{|c|}{ Outcomes: Infants' Health Outcomes } & \multicolumn{2}{|c|}{$\begin{array}{c}\text { Outcomes: Mothers' Health Behavior } \\
\text { During Pregnancy }\end{array}$} \\
\hline & Birth Weight & $\begin{array}{l}\text { Low Birth } \\
\text { Weight }\end{array}$ & Preterm Birth & Apgar Score & Prenatal Visits & $\begin{array}{l}\text { Month Prenatal } \\
\text { Care Began }\end{array}$ \\
\hline & (1) & (2) & (3) & (4) & (5) & (6) \\
\hline $\begin{array}{l}\text { UI Maximum } \\
\text { Benefit } \times \text { UI } \\
\text { Eligible }\end{array}$ & $\begin{array}{c}2.598^{\star \star \star} \\
(0.489)\end{array}$ & $\begin{array}{c}-0.002^{\star *} \\
(0.001)\end{array}$ & $\begin{array}{c}-0.003^{\star * *} \\
(0.001)\end{array}$ & $\begin{array}{c}0.021^{\star \star \star} \\
(0.005)\end{array}$ & $\begin{array}{c}0.089^{* * *} \\
(0.026)\end{array}$ & $\begin{array}{c}-0.042^{\star * *} \\
(0.009)\end{array}$ \\
\hline State FE & Yes & Yes & Yes & Yes & Yes & Yes \\
\hline Year FE & Yes & Yes & Yes & Yes & Yes & Yes \\
\hline States Controls & Yes & Yes & Yes & Yes & Yes & Yes \\
\hline State Trend & Yes & Yes & Yes & Yes & Yes & Yes \\
\hline$R^{2}$ & 0.85 & 0.59 & 0.61 & 0.70 & 0.85 & 0.81 \\
\hline Observations & 47,430 & 47,430 & 47,430 & 47,430 & 47,430 & 47,430 \\
\hline
\end{tabular}

Notes. Standard errors, reported in parentheses, are clustered at the state level. All dollar values are converted into 2000 dollars to reflect real values. All regressions are weighted using the average state-level birth counts over the sample period. ${ }^{* * *} p<0.01,{ }^{* *} p<0.05,{ }^{*} p<0.1$ 
Articles

\section{Figures}

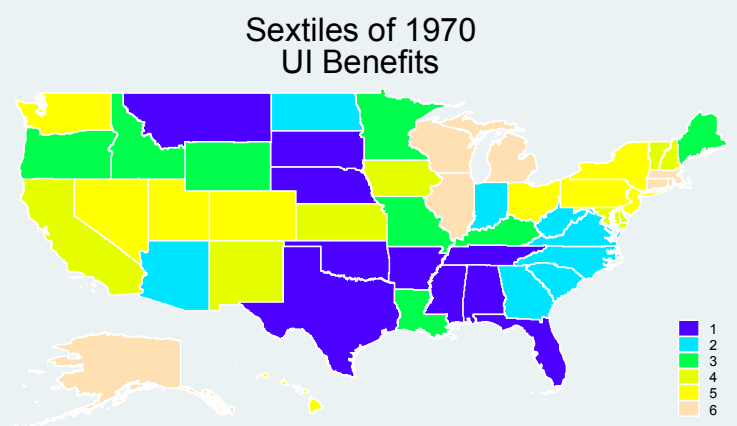

Sextiles of $1970-2000$

UI Benefits Increases

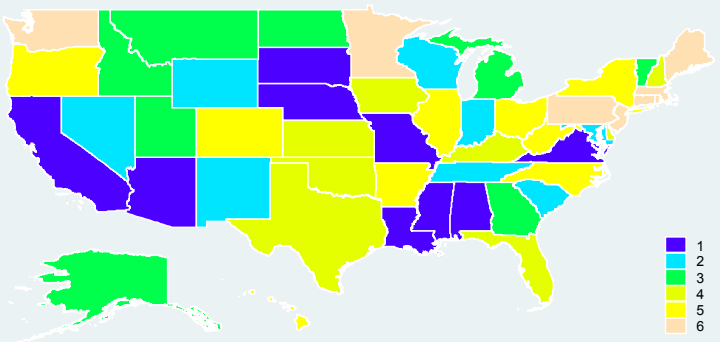

Figure 1: Geographic Distribution of UI Benefits at 1970 and Changes in Benefits over the Sample Period (1970-2000)

Sextiles of Child Mortality Rate at 2000

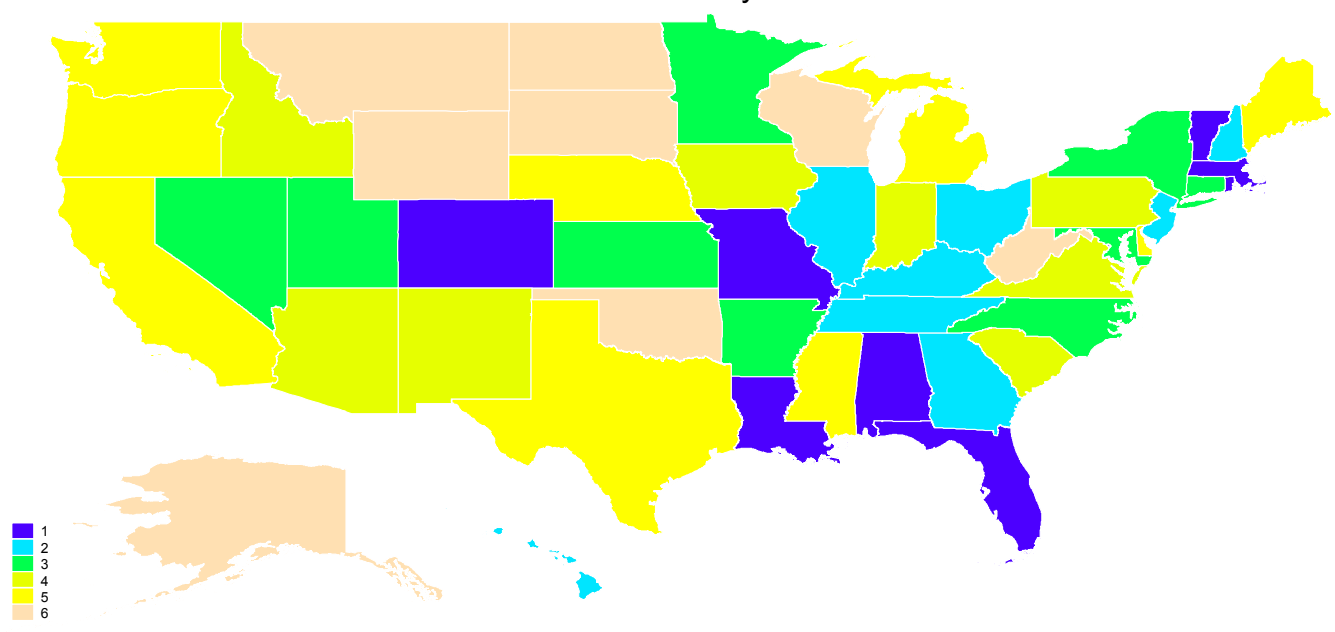

Figure 2: Geographic Distribution of Child Mortality Rates across the US States 